\title{
Comparison of Quality Traits of Thigh Meat from Korean Native Chickens and Broilers
}

\author{
Yeonkuk Jung, Hee Jun Jeon ${ }^{1}$, Samooel Jung, Jun Ho Choe, Jun Heon Lee, \\ Kang Nyeong $\mathrm{Heo}^{2}$, Bo Seok Kang${ }^{2}$, and Cheorun Jo* \\ Department of Animal Science and Biotechnology, Chungnam National University, Daejeon 305-764, Korea \\ ${ }^{1}$ Graduate School of Agricultural Biotechnology, Seoul National University, Seoul 151-921, Korea \\ ${ }^{2}$ Department of Poultry, National Institute of Animal Science, RDA, Sunghwan 331-801, Korea
}

\begin{abstract}
The quality attributes of thigh meat from a certified meat-type commercial Korean native chicken (Woorimatdag ${ }^{\mathrm{TM}}$, WM) and a commercial broiler (Ross, CB) raised under the same environmental conditions, were compared. One-d-old, mixedsex WM (200), and 200 broilers (Ross, CB) each were randomly assigned to floor pens (20 chickens per pen). The production stages (I, II, and III) were selected based on similar live weight. The crude fat contents of WM thigh meat were lower than those of CB. WM thigh meat contained higher stearic and arachidonic acid contents but lower palmitoleic and oleic acid contents compared to those of CB. The thigh meat color CIE L*- and CIE $\mathrm{b}^{*}$-values of WM were lower, but inosine5 '-monophosphate content was higher in WM than CB in whole production stages. WM thigh meat showed higher collagen content, hardness, springiness, gumminess, and chewiness than CB. In sensory evaluation, odor, taste, and overall acceptance were higher while color was lower in WM. Based on these results, it can be concluded that even if commercial broilers are raised under the same environmental conditions as WM, the unique quality attributes of WM thigh meat are distinctively unique.
\end{abstract}

Key words: Korean native chicken, broiler, thigh, environmental condition, quality attributes

\section{Introduction}

White meat such as chicken meat is considered superior in health compared to red meat due to its relatively lower contents of fat, cholesterol, and iron (Jaturasitha et al., 2008). The per capita consumption of chicken meat in Korea has increased rapidly from $1.4 \mathrm{~kg}$ in 1970 to $7.5 \mathrm{~kg}$ in 2005. Chicken meat consumption is expected to increase by $34 \%$ by the year 2018 with a concomitant fall in price of $15 \%$, which means that chicken will continue as the cheapest commercially produced meat (OECDFAO, 2009). Globally, however, this rapidly growing consumption of chicken meat is based on a few fast-growing broiler strains produced by commercial breeding companies in intensive fattening systems (Jaturasitha et al., 2008).

Native chicken breeds in Korea are characterized by poor commercial performance, including lower growth

*Corresponding author: Cheorun Jo, Department of Animal Science and Biotechnology, Chungnam National University, Daejeon 305-764, Korea, Tel: 82-42-821-5774, Fax: 82-42825-9754, E-mail: cheorun@cnu.ac.kr rate, feed efficiency, and lean muscle gaining ability than those of imported commercial synthetic breeds (CB) (Jeon et al., 2010). Similarly, the indigenous chickens of Thailand generally have a slower growth rate than CB. However, Thai indigenous chicken is considered as a delicacy due to its unique quality (Wattanachant et al., 2004). Usually, native chicken meats in different countries have a unique taste and texture that attract domestic consumers' preferences, thereby increasing the price about 2 3 times than that of CB (Ding et al., 1999).

Only a few farms in the remote areas of Korea raise native chicken breeds. In order to maintain this national resource, the National Institute of Animal Science, RDA, Korea, has conducted a native chicken breed restoration program. From this program, a commercial meat-type native chicken line was developed called Woorimatdag ${ }^{\mathrm{TM}}$ (WM), of which different quality characteristics were recently studied and compared with those of CB (Jeon et al., 2010). However, previous studies were limited since they compared the WM and CB samples under different growth environments. Meat quality is affected significantly by many factors such as genetics, age, body weight, 
feed, and other environmental conditions (Chen et al., 2002; Jaturasitha et al. 2008; Moore et al., 2008). Therefore, it is worth to investigate the differences in the quality characteristics of WM and CB when other environmental factors are controlled.

Therefore, the objective of this study was to compare the quality attributes of thigh meat from WM and CB raised under the same environmental conditions and slaughtered at the same production stage (similar slaughter weight).

\section{Materials and Methods}

\section{Animal and experimental design}

Two hundreds 1-day-old, mixed-sex Woorimatdag ${ }^{\mathrm{TM}}$ (WM, a certified meat-type commercial Korean native chicken breed, Gallus domesticus) along with 200 commercial broilers (CB, Ross) were obtained from a commercial hatchery. Chickens were randomly assigned to floor pens (20 chickens per pen, $3.0 \times 2.0 \mathrm{~m}$ ) under standard conditions of temperature, humidity, and ventilation, as well as $24 \mathrm{~h}$ fluorescent lighting for the entire experimental period. Chickens had ad libitum access to water and were fed a commercial broiler starter (0-6 d), grower (7-21 d), and finisher (21-35 and $77 \mathrm{~d}$ ) diet. The diet was comprised of approximately $20 \%$ crude protein, $4 \%$ crude fiber, and 3,100 ME kcal $/ \mathrm{kg}$, which is a typical commercial diet for broilers (Chunhajeil Feed Co., Korea). Chickens were weighed every week. The weeks that both chicken breeds had similar live weights were designated as the production stages: stage I, $1.14 \mathrm{~kg}$ for $\mathrm{WM}$ and $0.99 \mathrm{~kg}$ for CB; stage II, $1.57 \mathrm{~kg}$ for $\mathrm{WM}$ and $1.53 \mathrm{~kg}$ for $\mathrm{CB}$; and stage III, $1.99 \mathrm{~kg}$ for $\mathrm{WM}$ and $1.93 \mathrm{~kg}$ for CB. The chickens were killed by conventional neck cut, bled for $2 \mathrm{~min}$, feathers removed, and eviscerated. Thigh muscle was dissected from the carcasses after chilling at $4^{\circ} \mathrm{C}$ for $24 \mathrm{~h}$. The skin was then removed, and the muscles were trimmed of obvious fat and connective tissue. The thigh meat samples from five birds of each stage per breed (total of 15 birds of each breed) were vacuum-packed and then stored in a freezer at $-50^{\circ} \mathrm{C}$ until analysis.

\section{Proximate composition}

The proximate compositions of thigh meat from WM and $\mathrm{CB}$ were determined by the methods of AOAC (1995). Briefly, moisture content was measured by drying the samples $(2 \mathrm{~g})$ at $102^{\circ} \mathrm{C}$ for $15 \mathrm{~h}$. Crude protein content was measured by the Kjeldahl method (VAPO45, Gerhardt Ltd., Germany). The amount of nitrogen obtained was multiplied by 6.25 to calculate the crude protein con- tent. Crude fat content was measured by the Soxhlet extraction system (TT 12/A, Gerhardt Ltd., Germany). Crude ash content was measured by heating the sample ( 2 g) in a furnace set at $600^{\circ} \mathrm{C}$ overnight.

\section{pH, water holding capacity (WHC), and color val- ues}

To determine the $\mathrm{pH}$ values of thigh meat, $1 \mathrm{~g}$ of each sample was mixed with $9 \mathrm{~mL}$ of distilled water and homogenized with a homomixer (T25 basic, Ika Co., Germany) at $1,130 \mathrm{~g}$ for $1 \mathrm{~min}$. The homogenate was filtered (Filter paper, No. 1, Whatman International Ltd., Maidstone, England) and the $\mathrm{pH}$ determined using a $\mathrm{pH}$ meter (750P, Istek Co., Korea). The mean value from three repeated measurements of each sample was used.

WHC was determined according to the modified method of Ryoichi et al. (1993). The minced thigh meat sample (2 g) was placed into a centrifugation tube with filter paper (No. 4, Whatman International Ltd) and centrifuged at $6,710 \mathrm{~g}$ for $10 \mathrm{~min}$. The absorbed moisture in the filter paper was weighed, and the moisture content of the meat sample $(2 \mathrm{~g})$ prior to centrifugation was determined after drying at $102^{\circ} \mathrm{C}$ for $15 \mathrm{~h}$. The WHC of the meat samples was calculated as the percentage of remaining sample weight, which is subtracted from the absorbed moisture in the filter paper on the basis of the moisture content of the original meat sample.

The color value of thigh meat was measured on the surface of meat samples prepared with $4 \mathrm{~cm}$ diameter and $1.5 \mathrm{~cm}$ thickness using a colorimeter (Spectrophotometer, CM-3500d, Minolta, Japan). The values of lightness (CIE $\left.\mathrm{L}^{*}\right)$, redness (CIE $\mathrm{a}^{*}$ ), and yellowness (CIE $\mathrm{b}^{*}$ ) were obtained using the average value from three repeated measurements with different locations on the meat surface. Each color value was automatically analyzed by Spectra Magic Software (Minolta Inc., Japan).

\section{Fatty acid composition}

Fatty acid composition was analyzed by the method of Jung et al. (2010). Lipids were extracted from thigh meat samples by mixing meat samples $(10 \mathrm{~g})$ and $50 \mathrm{~mL}$ of Folch solution (chloroform: methanol $=2: 1$ ). To this solution, $0.88 \% \mathrm{KOH}$ was added, followed by vigorous mixing with a cap and incubation for $2 \mathrm{~h}$ at room temperature. Then, the upper layer was removed, and chloroform was evaporated using $\mathrm{N}_{2}$ gas $(99.999 \%)$. After cooling, 1 $\mathrm{mL}$ of methylating reagent $\left(\mathrm{BF}_{3}-\right.$ methanol, Sigma Chemical Co., USA) was added to $100 \mu \mathrm{L}$ of lipid, which was heated at $70^{\circ} \mathrm{C}$ for $30 \mathrm{~min}$. The samples were removed 
from the water bath and allowed to cool, after which 2 $\mathrm{mL}$ of hexane (HPLC grade) and $5 \mathrm{~mL}$ of distilled water were added to the samples. The samples were then vortexed and the upper layer removed. The fatty acid methyl ester dissolved in hexane was transferred to a GC vial. Fatty acid composition was analyzed using a gas chromatograph (GC 6890N, Agillent, USA) equipped with a mass selective detector. A split inlet (split ratio, 50:1) was used to inject samples into a HP-5MS capillary column ( $30 \mathrm{~m} \times 0.25 \mathrm{~mm} \times 0.25 \mu \mathrm{m}$ film thickness, Agillent, USA). The ramped oven temperature was $150^{\circ} \mathrm{C}$ for $3 \mathrm{~min}$, increased to $180^{\circ} \mathrm{C}$ at $2.5^{\circ} \mathrm{C} / \mathrm{min}$ and maintained for 5 min, and increased to $220^{\circ} \mathrm{C}$ at $2.5^{\circ} \mathrm{C} / \mathrm{min}$ and maintained for $25 \mathrm{~min}$. Inlet temperature was $210^{\circ} \mathrm{C}$ and the detector temperature $250^{\circ} \mathrm{C}$. Helium was the carrier gas at constant flow of $0.7 \mathrm{~mL} / \mathrm{min}$. The temperature of the mass spectrometer (MS) source, MS quadrupole, and transfer line into the MS were 230,150 , and $280^{\circ} \mathrm{C}$, respectively. The fatty acid composition was identified by a mass spectrum database (NIST Library, mass spectral search program, version 5.0, USA).

\section{Nucleotide content}

Thigh meat sample $(5 \mathrm{~g})$ was mixed with $25 \mathrm{~mL}$ of 0.7 $\mathrm{M}$ perchloric acid and centrifuged at 1,130 $\mathrm{g}$ for $1 \mathrm{~min}$ to extract nucleic acids. The extracted nucleic acids were centrifuged at 2,090 $\mathrm{g}$ for $15 \mathrm{~min}$ and then filtered through Whatman No.4 filter paper (Whatman International Ltd. USA). The supernatant was adjusted to $\mathrm{pH} 7$ with $5 \mathrm{~N}$ $\mathrm{KOH}$. The $\mathrm{pH}$-adjusted supernatant was placed into a volumetric flask and made up to $100 \mathrm{~mL}$ with $0.7 \mathrm{M}$ perchloric acid ( $\mathrm{pH}$ 7). After cooling for $30 \mathrm{~min}$, the supernatant was centrifuged at $1,130 \mathrm{~g}\left(0^{\circ} \mathrm{C}\right)$ and then filtered through a $0.2 \mu \mathrm{m}$ PVDF syringe filter (Whatman International Ltd.). The filtrate $(5 \mathrm{~mL})$ was analyzed using HPLC (ACME 9000, Younglin Instruments Inc, Korea). For the analytical conditions of the HPLC, Waters-Atlantis dC18 RP column $(4.6 \times 250 \mathrm{~mm}, 5 \mu \mathrm{m}$ particles, Waters Co., USA) was used. Mobile phase was $0.1 \mathrm{M}$ triethylamine in $0.15 \mathrm{M}$ acetonitrile ( $\mathrm{pH} 7.0$ ). The flow rate of the mobile phase was $1.0 \mathrm{~mL} / \mathrm{min}$, and the injection volume was 10 $\mu \mathrm{L}$. The column temperature was maintained at $35^{\circ} \mathrm{C}$, and the detection was monitored at a wavelength of $260 \mathrm{~nm}$. The peaks of the individual nucleotides were identified using the retention time for standards: hypoxanthine, inosine, inosine-5'-monophosphate (IMP), adenosine-5'monophosphate (AMP) (Sigma, USA), and the concentration was calculated using the area for each peak.

\section{Amino acids content}

Thigh meat sample $(10 \mathrm{~g})$ was mixed with $40 \mathrm{~mL}$ of 6 $\mathrm{N} \mathrm{HCl}$ and hydrolyzed at $110^{\circ} \mathrm{C}$ for $24 \mathrm{~h}$. The hydrolyzed meat sample was concentrated using a rotary evaporator (Eyela, Japan) to remove $\mathrm{HCl}$, and the residue was cleaned three times with distilled water and filtered using filter paper (No. 4, Whatman International Ltd.). The filtrate made up to $50 \mathrm{~mL}$ with distilled water was analyzed using an amino acid analyzer (Hitachi L-8500A, Japan). Before adding $\mathrm{HCl}$, cysteine and methionine were converted to cysteic acid and methione sulfone using $20 \mathrm{~mL}$ of a stabilizing solution ( $85 \%$ formic acid $45 \mathrm{~mL}+30 \%$ $\mathrm{H}_{2} \mathrm{O}_{2} 5 \mathrm{~mL}$ ).

\section{Total collagen content}

The total collagen content of thigh meat was determined by acid hydrolysis as described by Palka (1999). The sample $(500 \mathrm{mg}$ ) was hydrolyzed with $25 \mathrm{~mL}$ of $6 \mathrm{M}$ $\mathrm{HCl}$ at $110^{\circ} \mathrm{C}$ for $24 \mathrm{~h}$. The hydrolysate was clarified with active carbon, filtered, neutralized with $10 \mathrm{M}$ and $1 \mathrm{M}$ $\mathrm{NaOH}$, and diluted with distilled water to a final volume of $250 \mathrm{~mL}$. Hydrolysate $(4 \mathrm{~mL})$ and $2 \mathrm{~mL}$ of chloramine $\mathrm{T}$ solution $(1.41 \mathrm{~g}$ of chloramines $\mathrm{T}, 10 \mathrm{~mL}$ of distilled water, $10 \mathrm{~mL}$ of $n$-propanol, and $80 \mathrm{~mL}$ of citric buffer at $\mathrm{pH}$ 6) were mixed in a test tube and left for $20 \mathrm{~min}$ at room temperature. Then, $2 \mathrm{~mL}$ of 4-dimethyl-aminobenzaldehyde solution (10 g of p-DABA, $35 \mathrm{~mL}$ of $\mathrm{HClO}_{4}^{-}$ $60 \%$, and $65 \mathrm{~mL}$ of isopropanol) was added. The solutions were shaken and heated at $60^{\circ} \mathrm{C}$ for $20 \mathrm{~min}$. The samples were then cooled for $5 \mathrm{~min}$ in tap water and their absorbances measured at $558 \mathrm{~nm}$ using a spectrophotometer (DU 530, Beckman Instruments Inc., USA). The amount of hydroxyproline was determined from a standard curve. The total collagen content was calculated from hydroxyproline content using a coefficient of 7.25. The collagen content was expressed as mg collagen per $\mathrm{g}$ meat.

\section{Texture analysis}

Thigh meat sample was homogenized through a 6-mm plate, and patties $(4 \mathrm{~cm}$ diameter, $2 \mathrm{~cm}$ thickness, and 20 g weight) were prepared. Half of each patty was cooked to an internal temperature of $75^{\circ} \mathrm{C}$ to prepare cooked meat samples. The centers of the raw and cooked meat samples were compressed twice to $75 \%$ of their original height by a texture analyzer (Model A-XT2, Stable micro systems, UK) attached with a needle (15 mm diameter) at a test speed of $5.00 \mathrm{~mm} / \mathrm{s}$ and a trigger force of $0.005 \mathrm{~kg}$. 


\section{Sensory evaluation}

For the sensory evaluation, thigh meats were heated in boiling water for $1 \mathrm{~h}$ using a gas burner to an internal temperature of $85^{\circ} \mathrm{C}$. Meat samples $(2 \times 3 \times 1.5 \mathrm{~cm})$ were placed into coded white dishes and served with drinking water. Thirteen consumer panelists, mainly students and staff, recorded their preferences using a 9-point hedonic scales (1=unlike extremely, 5=like moderately, 9=like extremely). The sensory parameters tested were color, odor, taste, texture, and overall acceptance for cooked thigh meat. All samples were labeled with random 3-digit numbers and presented to panelists in random order. Whole sensory analysis was repeated the next day.

\section{Statistical analysis}

Analysis of variance was conducted by the procedure of General Linear Model using SAS program version 9.1 (2002-2003 by SAS Institute Inc.). Duncan's multiple range tests were used to compare the significant differences of the mean values of treatments $(p<0.05)$. Mean values and standard error of the means (SEM) are reported.

\section{Results and Discussion}

\section{Proximate composition}

The proximate compositions of $\mathrm{WM}$ and $\mathrm{CB}$ at similar production stages are shown in Table 1. The crude fat contents of WM thigh meat were significantly lower than those of $\mathrm{CB}$ at each production stage. This result is consistent with the reports of Young and Choi (2003). These authors reported that the fat contents of breast and thigh meat from traditional Korean chickens are lower than

Table 1. Proximate composition (\%) of thigh meat from Woorimatdag $^{\mathrm{TM}}$ (WM) and commercial broilers (CB)

\begin{tabular}{clcccl}
\hline $\begin{array}{c}\text { Production } \\
\text { stage }^{1)}\end{array}$ & Breed & Moisture & $\begin{array}{c}\text { Crude } \\
\text { fat }\end{array}$ & $\begin{array}{c}\text { Crude } \\
\text { protein }\end{array}$ & $\begin{array}{c}\text { Crude } \\
\text { ash }\end{array}$ \\
\hline \multirow{2}{*}{ I } & WM & 74.01 & $4.06^{\mathrm{b}}$ & 17.45 & 0.98 \\
& CB & 73.89 & $6.59^{\mathrm{a}}$ & 16.95 & 1.03 \\
& SEM $^{2}$ & 0.814 & 0.770 & 0.231 & 0.026 \\
\hline \multirow{2}{*}{ II } & WM & 75.03 & $4.00^{\mathrm{b}}$ & 17.43 & 1.05 \\
& CB & 74.40 & $5.80^{\mathrm{a}}$ & 16.97 & 0.99 \\
& SEM & 0.346 & 0.378 & 0.233 & 0.122 \\
\hline \multirow{2}{*}{ III } & WM & 75.34 & $3.14^{\mathrm{b}}$ & 17.63 & 1.25 \\
& CB & 74.36 & $6.18^{\mathrm{a}}$ & 16.90 & 0.99 \\
& SEM & 1.066 & 1.089 & 0.256 & 0.086 \\
\hline
\end{tabular}

$\overline{\mathrm{a}, \mathrm{b}}$ Means with different superscript within the same column with the same production stage differ significantly $(p<0.05)$.

${ }^{1)}$ Stage I, $1.14 \mathrm{~kg}$ of $\mathrm{WM}$ and $0.99 \mathrm{~kg}$ of CB; stage II, $1.57 \mathrm{~kg}$ of WM, $1.53 \mathrm{~kg}$ of CB, and stage III, $1.99 \mathrm{~kg}$ of WM, 1.93 of CB

${ }^{2}$ Standard errors of the mean $(n=10)$ those of commercial broilers. No differences in moisture, crude protein, or crude ash content were found between WM and CB meats. Therefore, the relatively low fat of WM thigh meat compared to $\mathrm{CB}$ at the same production stage can be considered a unique nutritional characteristic.

\section{pH, WHC, and color values}

The $\mathrm{pH}$ of WM thigh meat was higher at production stage II but lower at production stage III than that of CB (Table 2). Dadgar et al. (2011) reported that ultimate $\mathrm{pH}$ is the main factor affecting all quality attributes including color and WHC. Pre-slaughter stress can change muscle glycogen content and this affect the rate and extent of $\mathrm{pH}$ decline (Berri et al., 2007). Jeon et al. (2010) reported that the $\mathrm{pH}$ of commercial Korean native chicken thigh meat, which is not the same breed as WM in this study, is lower than that of commercial broiler at commercial stage (production stage III). The $\mathrm{pH}$ of Thai indigenous chicken thigh meat is also lower than that of commercial broiler (Wattanachant et al., 2004). Sung et al. (2000) compared the meat characteristics between Korean native chicken and Wangchoo, a dual purpose breed, and reported that the $\mathrm{pH}$ of leg meat was decreased by age regardless of strain without differences between the strains. The result of lower $\mathrm{pH}$ in leg meat of $\mathrm{CB}$ at production stage II cannot be clearly explained and further study is needed. The WHC of WM thigh meat was higher than that of CB only at production stage II, and no differences were observed at production stages I and III. Jeon et al. (2010) reported no difference in WHC between commercial Korean native chicken and broiler meat. The lightness value of

Table 2. pH, water holding capacity (WHC), and color values of thigh meat from Woorimatdag ${ }^{\mathrm{TM}}$ (WM) and commercial broilers (CB)

\begin{tabular}{cllcccc}
\hline $\begin{array}{c}\text { Production } \\
\text { stage }{ }^{1)}\end{array}$ & Breed & $\mathrm{pH}$ & $\begin{array}{c}\text { WHC } \\
(\%)\end{array}$ & CIE L* $^{*}$ & CIE a* & CIE b* $^{*}$ \\
\hline \multirow{2}{*}{ I } & WM & 6.47 & 63.31 & $47.58^{\mathrm{b}}$ & 7.94 & $13.04^{\mathrm{b}}$ \\
& $\mathrm{CB}$ & 6.48 & 58.44 & $50.31^{\mathrm{a}}$ & 8.90 & $17.76^{\mathrm{a}}$ \\
& SEM $^{2}$ & 0.014 & 4.077 & 0.711 & 0.446 & 0.527 \\
\hline \multirow{2}{*}{ II } & WM & $6.62^{\mathrm{a}}$ & $70.97^{\mathrm{a}}$ & $46.74^{\mathrm{b}}$ & $7.07^{\mathrm{b}}$ & $11.58^{\mathrm{b}}$ \\
& $\mathrm{CB}$ & $5.94^{\mathrm{b}}$ & $56.55^{\mathrm{b}}$ & $54.45^{\mathrm{a}}$ & $8.38^{\mathrm{a}}$ & $16.94^{\mathrm{a}}$ \\
& $\mathrm{SEM}$ & 0.003 & 1.740 & 0.787 & 0.408 & 0.676 \\
\hline \multirow{2}{*}{ III } & WM & $6.34^{\mathrm{b}}$ & 62.04 & $47.26^{\mathrm{b}}$ & 7.70 & $11.61^{\mathrm{b}}$ \\
& $\mathrm{CB}$ & $6.51^{\mathrm{a}}$ & 62.59 & $51.62^{\mathrm{a}}$ & 8.73 & $16.88^{\mathrm{a}}$ \\
& $\mathrm{SEM}$ & 0.009 & 1.498 & 0.954 & 0.470 & 0.521
\end{tabular}

$\overline{\mathrm{a}, \mathrm{b}}$ Means with different superscript within the same column with the same production stage differ significantly $(p<0.05)$.

${ }^{1)}$ See Table 1.

${ }^{2)}$ Standard errors of the mean $(n=10)$ 
WM was lower than that of $\mathrm{CB}$ in all production stages tested. Wattanachant et al. (2004) previously reported that the biceps femoris muscle of indigenous chicken has much higher values of brightness, redness, and yellowness than those of broiler, and they assumed that the result is probably related to differences in muscle $\mathrm{pH}$ between the breeds. Petracci et al. (2004) reported that paler chicken breast meat (CIE L*-value higher than 56) is characterized by lower $\mathrm{pH}$ and poorer WHC, whereas darker chicken breast meat $(<50)$ is associated with higher muscle $\mathrm{pH}$ and cooking yield. However, the relationship between color CIE L*-value and WHC was not consistent in this study. Only thigh meat from WM at production stage II showed higher CIE $\mathrm{a}^{*}$-values as well as lower CIE $b^{*}$-values in all production stages. Therefore, in general, WM thigh meat had lower CIE $\mathrm{L}^{*}$ - and CIE $b^{*}$ values and higher WHC than those of CB.

\section{Fatty acid composition}

Table 3 presents the major fatty acids of thigh meat of $\mathrm{WM}$ and $\mathrm{CB}$ at the same production stages. The major fatty acids of chicken thigh, including palmitic (C16:0), stearic (C18:0), oleic (C18:1), and linoleic acid (C18:2), were all consistent with previous results (Sung et al., 1998; Kim et al., 1999). WM thigh meat contained significantly higher stearic and arachidonic acid (C20:4) contents but lower palmitoleic (C16:1) and oleic acid contents than those of CB at each production stage. Jeon et al. (2010) showed consistent results that Korean native chickens have significantly higher content of arachidonic acid than CB. Similarly, Hinai-jidori, a Japanese native chicken breed, showed significantly higher arachidonic acid content than broiler in thigh meat (Rikimaru and Takahashi, 2010). Recently, Kiyohara et al. (2010) dem- onstrated that total taste intensity and aftertaste of both chicken soup and steamed minced meat were significantly higher when birds were fed arachidonic acid-enriched diet. The authors suggest that palatability of chicken meat can be improved by dietary arachidonic acid supplementation. However, the proportion of total unsaturated fatty acids (UFAs) was higher in CB thigh meat at production stages II and III mainly because of lower quantity of palmitoleic and oleic acid in WM.

On the other hand, essential fatty acids such as linoleic, linolenic, and arachidonic acid should be provided as a dietary supplement since they cannot be biogenerated in the body (Cho et al., 2008). Thus, relatively high arachidonic acid content of WM is also an attractive nutritional quality factor. The difference in fatty acid composition is possibly due to dietary differences (Cherian et al., 2002) as well as due to the differences in feeding behavior between the breeds (Wattanachant et al., 2004). In addition, this study also showed that genetic strain is an important factor affecting fatty acid composition among samples at different production stages.

\section{Nucleotides}

The content of nucleotides in $\mathrm{WM}$ and $\mathrm{CB}$, which can be associated with meat flavor, is shown in Table 4. IMP content of WM was higher than that of $\mathrm{CB}$ at production stage I and III. Ahn and Park (2002) reported that the concentrations of IMP in meats from Korean native chicken, aged $15 \mathrm{wk}$, are higher than those in commercial broiler, aged 6 wk. Rikimaru and Takayashi (2010) reported that the thigh meat from 22-wk-old Hinai-jidori had higher IMP content than that from 8-wk-old broiler when the same environmental conditions were given but no difference was observed 22-wk-old broiler. Chen et al. (2002)

Table 3. Fatty acid composition (\%) of thigh meat from Woorimatdag $^{\mathrm{TM}}$ (WM) and commercial broilers (CB)

\begin{tabular}{clcccccccccc}
\hline \hline $\begin{array}{c}\text { Production } \\
\text { stage }^{1)}\end{array}$ & Breed & C16:0 & C16:1 & C18:0 & C18:1 & C18:2 & C20:4 & C20:5 & C22:6 & SFA & UFA \\
\hline \multirow{2}{*}{ I } & WM & 23.87 & 2.54 & 19.38 & 30.56 & 18.94 & $2.38^{\mathrm{a}}$ & 0.61 & 1.72 & 43.26 & 56.74 \\
& CB & 24.39 & 3.21 & 16.92 & 31.72 & 19.71 & $1.57^{\mathrm{b}}$ & 0.55 & 1.95 & 41.30 & 58.70 \\
& $\mathrm{SEM}^{2)}$ & 0.291 & 0.306 & 0.823 & 0.900 & 0.257 & 0.141 & 0.040 & 0.189 & 1.063 & 1.063 \\
\hline \multirow{2}{*}{ II } & WM & 24.48 & $1.60^{\mathrm{b}}$ & $21.67^{\mathrm{a}}$ & $27.70^{\mathrm{b}}$ & 18.72 & $3.00^{\mathrm{a}}$ & $0.89^{\mathrm{a}}$ & 1.94 & $46.15^{\mathrm{a}}$ & $53.85^{\mathrm{b}}$ \\
& $\mathrm{CB}$ & 24.54 & $3.32^{\mathrm{a}}$ & $17.17^{\mathrm{b}}$ & $33.63^{\mathrm{a}}$ & 18.16 & $1.36^{\mathrm{b}}$ & $0.51^{\mathrm{b}}$ & 1.30 & $41.71^{\mathrm{b}}$ & $58.29^{\mathrm{a}}$ \\
& SEM & 0.157 & 0.057 & 0.433 & 0.257 & 0.215 & 0.118 & 0.022 & 0.174 & 0.396 & 0.396 \\
\hline \multirow{2}{*}{ III } & WM & 25.11 & $1.90^{\mathrm{b}}$ & $21.87^{\mathrm{a}}$ & $29.55^{\mathrm{b}}$ & $16.74^{\mathrm{b}}$ & 2.72 & 0.58 & 1.53 & $46.98^{\mathrm{a}}$ & $53.02^{\mathrm{b}}$ \\
& $\mathrm{CB}$ & 24.48 & $2.60^{\mathrm{a}}$ & $17.32^{\mathrm{b}}$ & $32.47^{\mathrm{a}}$ & $18.71^{\mathrm{a}}$ & 2.06 & 0.72 & 1.65 & $41.80^{\mathrm{b}}$ & $58.20^{\mathrm{a}}$ \\
& $\mathrm{SEM}$ & 0.303 & 0.177 & 0.412 & 0.662 & 0.299 & 0.231 & 0.051 & 0.189 & 0.238 & 0.238 \\
\hline
\end{tabular}

${ }^{\mathrm{a}, \mathrm{b}}$ Means with different superscript within the same column with the same production stage differ significantly $(p<0.05)$.

${ }^{1)}$ See Table 1.

${ }^{2)}$ Standard errors of the mean $(n=10)$ 
Table 4. Nucleotide content $(\mathrm{mg} / 100 \mathrm{~g})$ of thigh meat from Woorimatdag $^{\mathrm{TM}}$ (WM) and commercial broilers (CB)

\begin{tabular}{cllccc}
\hline \hline $\begin{array}{c}\text { Production } \\
\text { stage }^{1)}\end{array}$ & Breed & AMP $^{2)}$ & IMP $^{3)}$ & Inosine & $\begin{array}{c}\text { Hypo- } \\
\text { xanthine }\end{array}$ \\
\hline \multirow{2}{*}{ I } & WM & 4.67 & $170.71^{\mathrm{a}}$ & $30.49^{\mathrm{b}}$ & 26.52 \\
& CB & 4.79 & $124.79^{\mathrm{b}}$ & $57.68^{\mathrm{a}}$ & 29.98 \\
& SEM $^{4)}$ & 0.167 & 3.474 & 1.325 & 0.950 \\
\hline \multirow{2}{*}{ II } & WM & 4.78 & 124.53 & $35.74^{\mathrm{b}}$ & $31.77^{\mathrm{a}}$ \\
& CB & 4.98 & 137.69 & $77.58^{\mathrm{a}}$ & $15.46^{\mathrm{b}}$ \\
& SEM & 0.149 & 19.156 & 1.256 & 0.551 \\
\hline \multirow{2}{*}{ III } & WM & 5.24 & $231.56^{\mathrm{a}}$ & $31.40^{\mathrm{b}}$ & 19.75 \\
& CB & 5.09 & $154.80^{\mathrm{b}}$ & $60.13^{\mathrm{a}}$ & 20.33 \\
& SEM & 0.185 & 20.149 & 2.145 & 0.802 \\
\hline
\end{tabular}

${ }^{\mathrm{a}, \mathrm{b}}$ Means with different superscript within the same column with the same production stage differ significantly $(p<0.05)$.

${ }^{1)}$ See Table 1.

${ }^{2)}$ Adenosine-5'-monophosphate (AMP)

${ }^{3)}$ Inosine-5'-monophosphate (IMP)

${ }^{4)}$ Standard errors of the mean $(n=10)$

observed that body weight, but not age, has significant effects on IMP contents of chicken meat. The inosine contents of WM thigh meat were lower than those of CB through all whole production stages. The important meat flavor precursors include amino acids, peptides, and nucleotides (Moody, 1983). IMP is a flavor precursor (Manabe et al., 1991) and is used in conjugation with monosodium glutamate for a synergistic effect (Nguyen et al., 1985). The present result suggests that WM may have a desirable flavor due to higher content of IMP, which might have resulted in a higher taste score than $\mathrm{CB}$ in sensory test (Table 4).

\section{Amino acid composition and total collagen content}

In general, amino acid compositions of thigh meat from WM and CB were not different with some minor exceptions (Table 5). Amino acids such as asparagine, threonine, serine, glutamic acid, glycine, and alanine are known to be associated with tasty flavor, whereas valine, isoleucine, leucine, phenyalanine, methionine, arginine, and proline are associated with bitter taste (Fukunaga et al., 1989). The contents of glycine, isoleucine, and valine were higher in WM at production stage I than in CB. However there was no difference found in production stages II and III, except for glycine, which also showed a difference in stage II. In contrast, Ahn and Park (2002)

Table 5. Amino acid content (\%) of thigh meat from Woorimatdag $^{\mathrm{TM}}$ (WM) and commercial broilers (CB)

\begin{tabular}{|c|c|c|c|c|c|c|c|c|c|}
\hline \multirow{3}{*}{ Amino acid } & \multicolumn{9}{|c|}{ Production stage $^{1)}$} \\
\hline & \multicolumn{2}{|c|}{ I } & \multicolumn{3}{|c|}{ II } & \multicolumn{4}{|c|}{ III } \\
\hline & WM & $\mathrm{CB}$ & $\mathrm{SEM}^{2)}$ & WM & $\mathrm{CB}$ & SEM & WM & $\mathrm{CB}$ & SEM \\
\hline Aspartic acid & 1.91 & 1.83 & 0.037 & 1.88 & 1.88 & 0.026 & 1.93 & 1.83 & 0.020 \\
\hline Threonine & 0.93 & 0.88 & 0.019 & 0.92 & 0.92 & 0.015 & 0.94 & 0.89 & 0.018 \\
\hline Serine & 0.83 & 0.81 & 0.015 & 0.83 & 0.85 & 0.013 & 0.85 & 0.81 & 0.012 \\
\hline Glutamic acid & 3.17 & 3.05 & 0.052 & 3.14 & 3.21 & 0.057 & 3.23 & 3.08 & 0.050 \\
\hline Glycine & $0.97^{\mathrm{a}}$ & $0.84^{\mathrm{b}}$ & 0.018 & $1.00^{\mathrm{a}}$ & $0.89^{b}$ & 0.009 & 0.96 & 0.88 & 0.029 \\
\hline Alanine & 1.19 & 1.10 & 0.019 & 1.16 & 1.15 & 0.012 & 1.18 & 1.11 & 0.012 \\
\hline Valine & $0.81^{\mathrm{a}}$ & $0.70^{\mathrm{b}}$ & 0.010 & 0.80 & 0.75 & 0.023 & 0.81 & 0.74 & 0.051 \\
\hline Isoleucine & $0.77^{\mathrm{a}}$ & $0.66^{\mathrm{b}}$ & 0.014 & 0.73 & 0.72 & 0.024 & 0.77 & 0.72 & 0.020 \\
\hline Leucine & 1.69 & 1.58 & 0.033 & 1.66 & 1.65 & 0.027 & 1.70 & 1.59 & 0.037 \\
\hline Phenylalanine & 0.78 & 0.72 & 0.016 & 0.78 & 0.75 & 0.014 & $0.78^{\mathrm{a}}$ & $0.73^{\mathrm{b}}$ & 0.010 \\
\hline Methionine & 0.43 & 0.42 & 0.010 & 0.46 & 0.43 & 0.023 & 0.46 & 0.41 & 0.032 \\
\hline Arginine & 1.21 & 1.13 & 0.023 & 1.21 & 1.20 & 0.019 & 1.21 & 1.15 & 0.017 \\
\hline Proline & 0.87 & 0.79 & 0.023 & 0.86 & 0.84 & 0.020 & 0.87 & 0.80 & 0.021 \\
\hline Cysteine & 0.21 & 0.22 & 0.006 & 0.22 & 0.21 & 0.006 & 0.22 & 0.21 & 0.005 \\
\hline Tyrosine & 0.59 & 0.57 & 0.014 & 0.59 & 0.58 & 0.006 & 0.60 & 0.56 & 0.010 \\
\hline Lysine & 1.72 & 1.61 & 0.036 & 1.69 & 1.70 & 0.034 & 1.76 & 1.63 & 0.028 \\
\hline Histidine & 0.53 & 0.52 & 0.010 & 0.54 & 0.54 & 0.012 & 0.55 & 0.52 & 0.012 \\
\hline Tasty A.A ${ }^{3)}$ & 9.03 & 8.52 & 0.170 & 8.96 & 8.92 & 0.133 & 9.10 & 8.63 & 0.113 \\
\hline Bitter A.A ${ }^{4)}$ & 6.58 & 6.05 & 0.140 & 6.53 & 6.36 & 0.139 & 6.63 & 6.16 & 0.131 \\
\hline Tasty A.A/Bitter A.A & 1.40 & 1.35 & & 1.40 & 1.37 & & 1.41 & 1.34 & \\
\hline
\end{tabular}

${ }^{\mathrm{a}, \mathrm{b}}$ Means with different superscript within the same row with the same production stage differ significantly $(p<0.05)$.

${ }^{1)}$ See Table 1.

${ }^{2)}$ Standard errors of the mean $(n=10)$

${ }^{3)}$ Tasty A.A: Sum of asparagine, threonine, serine, glutamic acid, glycine, and alanine

${ }^{4)}$ Bitter A.A: Sum of valine, isoleucine, leucine, phenyalanine, methionine, arginine, and proline 


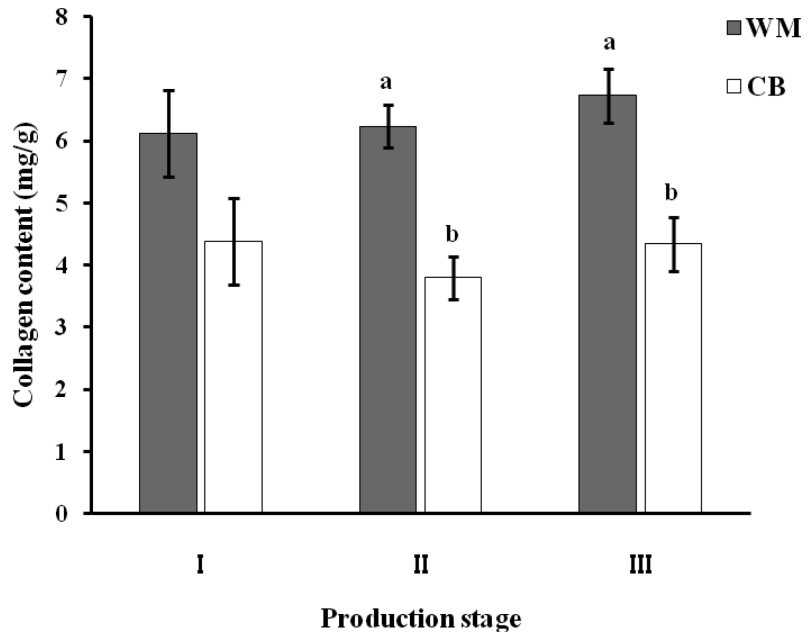

Fig. 1. Collagen content of raw thigh meat from Woorimat$\operatorname{dag}^{\mathrm{TM}}$ (WM) and commercial broilers (CB). ${ }^{\mathrm{a}, \mathrm{b}}$ Means with different superscript within the same production stage differ significantly $(p<0.05) .{ }^{1)}$ See Table 1 .

previously observed that the ratio of good-tasting amino acids to bitter-tasting amino acids is higher in Korean native chicken at 6 weeks of age compared to broiler thigh meat.

WM thigh meat contained significantly higher total collagen content than $\mathrm{CB}$ at production stages II and III (Fig. 1). Jeon et al. (2010) also reported that WM contains higher content of total collagen than $\mathrm{CB}$ at commercial stage, which was also production stage III in this study. Wattanachant et al. (2004) reported that the total collagen contents of Thai indigenous chicken are higher than that of broiler. Ding et al. (1999) also reported that Chinese local chickens have significantly higher total collagen than broiler. Jaturasitha et al. (2008) demonstrated that the shear force of chicken thigh meat is positively correlated with its collagen content.

\section{Texture and sensory analysis}

Tables 6 and 7 show the texture properties of raw and cooked meat of $\mathrm{WM}$ and $\mathrm{CB}$, respectively. In raw meat, the values of hardness, springiness, gumminess, and chewiness were higher in thigh meat from WM as compared to $\mathrm{CB}$. Similar results reported that the shear values of Thai indigenous chicken meats, aged $16 \mathrm{wk}$, either raw or cooked, are higher than those of broiler muscles, aged $38 \mathrm{~d}$, at similar live weights $(1.5 \pm 0.2 \mathrm{~kg})$ (Watanachant $e t$ al., 2004).

The results of the sensory evaluation are shown in Table 8. Sensory panelists preferred the color of thigh meat from CB compared to that from WM. Jeon et al. (2010) reported that the sensory panelists preferred thigh meat
Table 6. Texture profile analysis of raw thigh meat from Woorimatdag $^{\mathrm{TM}}$ (WM) and commercial broilers (CB)

\begin{tabular}{cllllll}
\hline \hline $\begin{array}{c}\text { Production } \\
\text { stage }^{1)}\end{array}$ & Breed & $\begin{array}{c}\text { Hardness } \\
(\mathrm{kg})\end{array}$ & $\begin{array}{c}\text { Springi- } \\
\text { ness } \\
(\mathrm{mm})\end{array}$ & $\begin{array}{c}\text { Cohe- } \\
\text { siveness } \\
(\%)\end{array}$ & $\begin{array}{c}\text { Gummi- } \\
\text { ness } \\
(\mathrm{kg})\end{array}$ & $\begin{array}{c}\text { Chewi- } \\
\text { ness } \\
(\mathrm{kg})\end{array}$ \\
\hline \multirow{2}{*}{ I } & WM & $0.31^{\mathrm{a}}$ & $0.96^{\mathrm{a}}$ & 0.44 & $0.13^{\mathrm{a}}$ & $0.13^{\mathrm{a}}$ \\
& $\mathrm{CB}$ & $0.19^{\mathrm{b}}$ & $0.89^{\mathrm{b}}$ & 0.48 & $0.09^{\mathrm{b}}$ & $0.08^{\mathrm{b}}$ \\
& $\mathrm{SEM}^{2)}$ & 0.019 & 0.015 & 0.020 & 0.006 & 0.007 \\
\hline \multirow{2}{*}{ II } & WM & $0.38 \mathrm{a}$ & 0.94 & 0.44 & $0.17 \mathrm{a}$ & $0.16 \mathrm{a}$ \\
& $\mathrm{CB}$ & $0.28 \mathrm{~b}$ & 0.95 & 0.45 & $0.12 \mathrm{~b}$ & $0.12 \mathrm{~b}$ \\
& SEM & 0.016 & 0.029 & 0.015 & 0.008 & 0.004 \\
\hline \multirow{2}{*}{ III } & WM & 0.37 & 0.96 & 0.42 & 0.16 & 0.15 \\
& CB & 0.32 & 0.95 & 0.44 & 0.14 & 0.13 \\
& SEM & 0.020 & 0.011 & 0.010 & 0.006 & 0.005 \\
\hline
\end{tabular}

$\overline{\mathrm{a}, \mathrm{b}}$ Means with different superscript within the same column with the same production stage differ significantly $(p<0.05)$.

${ }^{1)}$ See Table 1.

${ }^{2)}$ Standard errors of the mean $(n=10)$

Table 7. Texture profile analysis of cooked thigh meat from Woorimatdag $^{\mathrm{TM}}$ (WM) and commercial broilers (CB)

\begin{tabular}{cllllll}
\hline \hline $\begin{array}{c}\text { Production } \\
\text { stage }^{1)}\end{array}$ & Breed & $\begin{array}{c}\text { Hardness } \\
(\mathrm{kg})\end{array}$ & $\begin{array}{c}\text { Springi- } \\
\text { ness } \\
(\mathrm{mm})\end{array}$ & $\begin{array}{c}\text { Cohe- } \\
\text { siveness } \\
(\%)\end{array}$ & $\begin{array}{c}\text { Gummi- } \\
\text { ness } \\
(\mathrm{kg})\end{array}$ & $\begin{array}{c}\text { Chewi- } \\
\text { ness } \\
(\mathrm{kg})\end{array}$ \\
\hline \multirow{2}{*}{ I } & WM & 4.81 & 0.84 & $0.42^{\mathrm{a}}$ & $2.02^{\mathrm{a}}$ & $1.69^{\mathrm{a}}$ \\
& $\mathrm{CB}$ & 4.02 & 0.83 & $0.29^{\mathrm{b}}$ & $1.15^{\mathrm{b}}$ & $0.96^{\mathrm{b}}$ \\
& $\mathrm{SEM}^{2)}$ & 0.209 & 0.011 & 0.022 & 0.162 & 0.145 \\
\hline \multirow{2}{*}{ II } & WM & 5.40 & $0.85^{\mathrm{a}}$ & 0.42 & 2.27 & 1.93 \\
& $\mathrm{CB}$ & 5.25 & $0.80^{\mathrm{b}}$ & 0.33 & 1.75 & 1.41 \\
& $\mathrm{SEM}$ & 0.225 & 0.007 & 0.031 & 0.176 & 0.154 \\
\hline \multirow{2}{*}{ III } & WM & 5.37 & 0.83 & $0.41^{\mathrm{a}}$ & $2.21^{\mathrm{a}}$ & $1.84^{\mathrm{a}}$ \\
& $\mathrm{CB}$ & 5.31 & 0.80 & $0.28^{\mathrm{b}}$ & $1.50^{\mathrm{b}}$ & $1.21^{\mathrm{b}}$ \\
& $\mathrm{SEM}$ & 0.165 & 0.009 & 0.031 & 0.177 & 0.154 \\
\hline
\end{tabular}

${ }^{\mathrm{a}, \mathrm{b}}$ Means with different superscript within the same column with the same production stage differ significantly $(p<0.05)$.

${ }^{1)}$ See Table 1.

${ }^{2)}$ Standard errors of the mean $(n=10)$.

Table 8. Comparison of sensory characteristics of thigh meat and soup between Woorimatdag ${ }^{\mathrm{TM}}$ (WM) and broiler (CB)

\begin{tabular}{lccccc}
\hline \hline Breed & Color & Odor & Taste & Texture & $\begin{array}{c}\text { Overall } \\
\text { acceptance }\end{array}$ \\
\hline $\mathrm{WM}$ & $4.96^{\mathrm{b}}$ & $5.86^{\mathrm{a}}$ & $6.13^{\mathrm{a}}$ & 5.56 & $6.00^{\mathrm{a}}$ \\
$\mathrm{CB}$ & $5.83^{\mathrm{a}}$ & $5.13^{\mathrm{b}}$ & $4.83^{\mathrm{b}}$ & 5.33 & $4.76^{\mathrm{b}}$ \\
SEM $^{1)}$ & 0.221 & 0.204 & 0.229 & 0.262 & 0.241 \\
\hline
\end{tabular}

${ }^{\mathrm{a}, \mathrm{b}}$ Means with different superscript within the same column with the same average weight between 2 breeds differ significantly $(p<0.05)$.

${ }^{1)}$ Standard errors of the mean $(n=4)$

from commercial South Korean native chicken (SKNC) and broiler to that from North Korean native chicken (NKNC), due to the strong dark color of NKNC without 
any difference between SKNC and broilers. However, the scores of odor, taste, and overall acceptance were significantly higher in thigh meat from WM compared to CB.

Based on the results, it can be concluded that thigh meat from Korean native chicken (Woorimatdag ${ }^{\mathrm{TM}}$ ) has several unique taste and textural quality characteristics when compared with commercial broilers, even when raised under the same environmental conditions. In general, the difference in quality attributes between Korean native chicken and commercial broiler do not change significantly at similar live weights at different production stages.

\section{Acknowledgement}

This work was carried out with the support of the "Cooperative Research Program for Agriculture Science \& Technology Development (Project No. PJ907011042011)" Rural Development Administration, Korea.

\section{References}

1. Ahn, D. H. and Park, S. Y. (2002) Studies on components related to taste such as free amino acids and nucleotides in Korean native chicken meat. J. Korean Soc. Food Sci. Nutr. 31, 547-552.

2. AOAC (1995) Official Method of Analysis. 16th ed, Association of official Analytilal chemists, Washington, DC.

3. Berri, C., LeBihan-Duval, E., Debut, M., Sante-Lhoutellier, V., Baeza, E., Gigaud, V., Jego, Y., and Duclos, M. J. (2007) Consequence of muscle hypertrophy on characteristics of Pectoralis major muscle and breast meat quality of broiler chickens. J. Anim. Sci. 85, 2005-2011.

4. Chen, G. H., Li, H. F., Wu, X. S., Li, B. C., Xie, K. Z., Dai, G. J., Chen, K. W., Zhang, X. Y., and Wang, K. H. (2002) Factors affecting the inosine monophosphate content of muscles in Taihe silkies chickens. Asian-Aust. J. Anim. Sci. 15, 1359-1363.

5. Cherian, G., Selvaraj, R. K., Goeger, M. P., and Stitt, P. A. (2002) Muscle fatty acid composition and thiobarbituric acid-reactive substances of broilers fed different cultivars of sorghum. Poultry Sci. 81, 1415-1420.

6. Dadgar, S., Lee, E. S., Leer, T. L. V., Crowe, T. G., Classen, H. L., and Shand, P. J. (2011) Effect of acute cold exposure, age, sex, and lairage on broiler breast meat quality. Poultry Sci. 90, 444-457.

7. Ding, H., Xu, R. J., and Chan, D. K. O. (1999) Identification of broiler chicken meat using a visible/near infrared spectroscopic technique. J. Sci. Food Agric. 79, 1382-1388.

8. Fukunaga, T., Koga, K., Maita, Y., and Matsuoka, S. (1989) Free amino acid, carnosine and 5'-inosinic acid contents in the breast and leg meats from the cross and tripe-cross chickens of Satsuma native fowl. Bull. Fac. Agric. Kagoshima
Univ. 39, 223-232.

9. Jaturasitha, S., Srikanchai, T., Kreuzer, M., and Wicke, M. (2008) Difference in carcass and meat characteristics between chicken indigenous to northern Thailand (blackboned and Thai native) and imported extensive breeds (Bresse and Rhode Island Red). Poultry Sci. 87, 160-169.

10. Jeon, H. J., Choe, J. H., Jung, Y., Kruk, Z. A., Lim, D. G., and Jo, C. (2010) Comparison of chemical composition, textural characteristics, and sensory properties between north and south Korean native chickens and commercial broilers. Korean J. Food Sci. Ani. Resour. 30, 171-178.

11. Jung, S., Choe, J.H., Kim, B., Yun, H., Kruk, Z.A., and Jo, C. (2010). Effect of dietary mixture of gallic acid and linoleic acid on antioxidative potential and quality of breast meat from broilers. Meat Sci. 86, 520-526.

12. Kim, Y. H., Min, J. S., Hwang, S. G., Lee, S. O., Kim, I. S., Park, H. I., and Lee, M. H. (1999) Fatty acids composition and sensory characteristics of the commercial native chicken meat. Korean J. Food Sci. Technol. 31, 964-970.

13. Kiyohara, R., Yamaguchi, S., Rikimaru, K., and Takahashi, H. (2010) Supplemental arachidonic acid-enriched oil improves the taste of thigh meat of Hinai-jidori chickens. Poultry Sci. 90, 1817-1822.

14. Manabe, K. M., Matoba, T., and Hasegawa, K. (1991) Sensory changes in umami taste of inosine-5'-monophosphate solution after heating. J. Food Sci. 56, 1429-1432.

15. Moody, W. G. (1983) Beef flavour- a review. Food Technol. 37, 227-232.

16. Moore, S.M., Stalder, K. J., Beitz, D. C., Stahl, C. H., Fithian, W. A., and Bregendahl, K. (2008) The correlation of chemical and physical corn kernel traits with production performance in broiler chickens and laying hens. Poultry Sci. 87, 665-676.

17. Nguyen, T. T. and Sporns, P. (1985) Decomposition of flavor enhancers, monosodium glutamate, inosine-5'-monophosphate and guanosine-5'-monophosphate during canning. $J$. Food Sci. 50, 812-814.

18. OECD-FAO (2009). Agricultural Outlook 2009-2018. Organization for Economic Cooperation and Development - Food and Agriculture Organization of the United Nation. Available from: http://www.agri-outlook.org/dataoecd/2/31/43040036.pdf.

19. Palka, K. (1999) Changes in intramuscular connective tissue and collagen solubility of bovine M.semitendinosus during retorting. Meat Sci. 53, 189-194.

20. Petracci, M., Betti, M., Bianchi, M., and Cavani, C. (2004) Color variation and characterization of broiler breast meat during processing in Italy. Poultry Sci. 83, 2086-2092.

21. Rikimaru, K. and Takahashi, H. (2010) Evaluation of the meat from Hinai-jidori chickens and broilers: Analysis of general biochemical components, free manio acids, inosine 5'-monophosphate, and fatty acids. J. Appl. Poult. Res. 19, 327-333.

22. Ryoichi, S., Degychi, T., and Nagata, Y. (1993) Effectiveness of the filter paper press methods for determining the water holding capacity of meat. Fleischwirtsch 73, 1399.

23. Sung, S. K., Kwon, Y. J., and Kim, D. G. (1998) Postmortem 
changes in the physico-chemical characteristics of Korean native chicken. Korean J. Poult. Sci. 25, 55-64.

24. Sung, S. K., Yang, T. M., Kwon, Y. J., Choi, J. D., and Kim, D. G. (2010) The quality characteristics of Korean native chicken by the age. Korean J. Anim. Sci. Technol. 42, 693702.

25. Wattanachant, S., Benjakul, S., and Ledward, D. A. (2004) Composition, color, and texture of Thai indigenous and broiler chicken muscles. Poultry Sci. 83, 123-128.

26. Young, H. T. and Choi, H. J. (2003) Studies on nutrient components between the Chungjung chicken meats and general chicken meats. Korean J. Food Nutr. 16, 187-191.

(Received 2011.7.15/Revised 1st 2011.9.7, 2nd 2011.9.27/ Accepted 2011.9.27) 